\author{
Aldona Malgorzata Dereń \\ Wydział Informatyki i Zarządzania \\ Politechnika Wrocławska \\ e-mail: aldona.deren@pwr.edu.pl
}

Jan Skonieczny

Wydział Informatyki i Zarządzania

Politechnika Wrocławska

e-mail: jan.skonieczny@pwr.edu.pl

\title{
ROLA WŁADZY W ORGANIZACJI SIECIOWEJ
}

\section{Abstract \\ The role of the power in the network organization}

The paper presents the role of the power in the network organization. This role is reflected in the analysis of free exchange and the voluntary sharing of power and knowledge in the network structure. Most often, the problem of the functioning of a network structure is described by depicting it in opposition to a hierarchical structure, indicating that the network is a structure without a single decision center and no fixed relations. According to the authors of the study, the network logic that replaces the hierarchy does not mean the complete disappearance of the centers of power. They remain, but in organizations with varied technical knowledge, competencies and experience. In a hierarchical structure, power is the means and purpose of acquiring and managing knowledge. On the other hand, network logic from knowledge makes the tool of gaining power. In the opinion of authors the network organization is not an alternative form for managing contemporary organizations. It is just a modernized management form using communication and information technologies and cooperation between organizations in the network.

Keywords: network organization, power, knowledge, exchanging, sharing

\section{Streszczenie}

W niniejszym artykule przedstawiono rolę władzy w organizacji sieciowej. Rola ta została ukazana na tle analizy swobodnej wymiany i dobrowolnego dzielenia się zasobami władzy i wiedzy w strukturze sieciowej. Najczęściej problematykę funkcjonowania struktury sieciowej opisuje się, przedstawiając ją w opozycji do struktury hierarchicznej, wskazując, że sieć to struktura nieposiadająca jednego centrum decyzyjnego i żadnych stałych relacji. Zdaniem autorów opracowania logika sieciowa, która zastępuje hierarchię, nie oznacza całkowitego zniknięcia ośrod- 
ków władzy. Pozostają one nadal, ale w organizacjach posiadających zróżnicowaną wiedzę techniczną, kompetencje i doświadczenia. W strukturze hierarchicznej władza jest środkiem i celem zdobywania zasobów wiedzy i zarządzania nimi. W organizacji sieciowej wiedza jest narzędziem zdobycia i utrzymania władzy. Według autorów sieć nie jest alternatywną formą zarządzania współczesnymi organizacjami. Jest to tylko nowoczesna forma zarządzania wykorzystująca technologie informacyjno-komunikacyjne i współpracę między uczestnikami sieci.

Słowa kluczowe: organizacja sieciowa, władza, wiedza, wymiana, dzielenie się

\section{Wprowadzenie}

Otoczenie, w którym funkcjonują współczesne organizacje, to dynamicznie i ciągle zmieniające się środowisko. Skalę i zakres zachodzących w nim zmian wyznaczają m.in.: rozwój technologii informatyczno-komunikacyjnych, wzrost znaczenia wiedzy i zasobów intelektualnych w gospodarce oraz odpowiedzialność społeczna organizacji wobec wszystkich aktorów rynkowych. Zmiany sprzyjają transformacji ekonomicznej, społecznej i kulturowej, porównywalnej zdaniem Manuela Castellsa do zmian wywołanych rewolucją techniczną, której początki sięgają XVIII wieku [Castells, 2007: 52-84]. W przeciwieństwie jednak do zmian będących początkiem rewolucji przemysłowej, obecne zmiany mają jakościowo inny charakter, ponieważ są implikowane rozwojem Internetu przedmiotów (ang. Internet of Things, IoT), którego funkcjonowanie warunkuje integracja procesów komunikacyjnych, energetycznych i logistycznych w organizacji i poza nią. Jak pisze Jeremy Rifkin, Internet przedmiotów

[...] połączy wszystko ze wszystkim w zintegrowaną sieć globalną. Ludzie, maszyny, zasoby naturalne, linie produkcyjne, sieci logistyczne, nawyki konsumpcyjne, przepływy recyklingowe oraz prawie każdy z pozostałych aspektów życia gospodarczego i społecznego zostaną podłączone za pośrednictwem czujników i oprogramowania do platformy IoT, nieustannie przesyłając big data (wielkie bazy danych) do każdego węzła - firm, domów, pojazdów - chwila za chwilą, w czasie rzeczywistym [Rifkin, 2016: 20].

Połączenie ,wszystkiego i wszystkich” w jedną wspólną sieć przyczyni się, zdaniem J. Rifkina, do narodzin organizacji zerowych kosztów krańcowych i rozwoju modeli organizacji życia gospodarczego opartych na wspólnocie współpracy [Rifkin, 2016: 25].

W niniejszej pracy opisana zostanie istota sieciowego rozwoju organizacji opartego na relacjach pomiędzy uczestnikami sieci. Podstawą tworzenia tych relacji jest swobodna wymiana i dobrowolne dzielenie się zasobami władzy i wiedzy wewnątrz sieci. Najczęściej problematykę funkcjonowania struktury sieciowej opisuje się, przedstawiając ją w opozycji do struktury hierarchicznej, wskazując, że sieć to struktura nieposiadająca jednego centrum decyzyjnego i żadnych stałych relacji. Zdaniem autorów pracy logika sieciowa, która zastępuje hierarchię, 
nie oznacza całkowitego zniknięcia ośrodków władzy. Pozostają one nadal, ale w organizacjach posiadających zróżnicowaną wiedzę techniczną, kompetencje i doświadczenia. W strukturze hierarchicznej władza jest środkiem i celem zdobywania zasobów wiedzy i zarządzania nimi. Natomiast logika sieciowa z wiedzy czyni narzędzie zdobycia władzy.

Autorzy niniejszego artykułu formułują pogląd, że nie każda sieć jest alternatywną i efektywną formą w zarządzaniu współczesnymi organizacjami. Jest to tylko zmodernizowana (przez technologie komunikacyjno-informatyczne) forma zarządzania. Manuel Castells w pracy Władza komunikacji stwierdza, że aczkolwiek mocną stroną sieci jest ich elastyczność, adaptacyjność oraz zdolność do samokonfiguracji, jednak w ,warunkach przedelektronicznych technologii komunikacyjnych", po przekroczeniu pewnej wielkości, złożoności i natężenia strumienia komunikacji społecznej (przekazu), sieci stają się mniej efektywne niż organizacje hierarchiczne, ponieważ są one oparte na rozkazach i kontroli, a nie na wzajemnych relacjach jak sieci [Castells, 2013: 34]. Wyrażony przez M. Castellsa pogląd skłania do zadania pytania o istotę władzy $\mathrm{i}$ jej relację z wiedzą w organizacji sieciowej.

\section{Sieć organizacyjna i jej elementy}

Według M. Castellsa najlepszą współcześnie formą organizacyjną pozwalającą na budowanie wzajemnych relacji jest forma sieciowa. Uzasadniając sieciową logikę rozwoju organizacji, odwołuje się do prac Kevina Kelly’ego, który pisał:

Symbolem nauki [w XXI wieku - A.M.D. i J.S.] jest dynamiczna sieć. [...]. Gdy atom wyraża czystą prostotę, sieć ukierunkowuje bezładną energię złożoności. [...] Jedyną organizacją zdolną do wolnego od nastawień rozwoju lub do swobodnego uczenia się jest sieć. Wszystkie inne topologie ograniczają to, co może się wydarzyć. Gąszcz sieci składa się z samych krawędzi i dlatego można w nią wejść w różnych miejscach. Sieć jest bodaj najmniej uporządkowaną organizacją z tych, o których można powiedzieć, że mają jeszcze w ogóle jakiś porządek. [...] W istocie, mnogość rzeczywiście rozbieżnych elementów może pomieścić się obok siebie tylko w sieci. Żaden inny układłańcuch, piramida, drzewo, koło, węzeł - nie może w sobie zawrzeć prawdziwej różnorodności, działając jako całość ${ }^{2}$ [Kelly, 1994: 25-27].

Nie ma jednoznacznych poglądów co do pojęcia sieci i organizacji sieciowej. Świadczą o tym różne opinie autorów, charakterystyczne dla języka, narracji czy kontekstu dotyczącego sieci.

Pojęcie sieci wywodzi się często ze sfery relacji międzyludzkich; można wskazać za Johnem Naisbittem, że sieci tworzą ludzie, rozmawiający ze sobą, zaangażowani, dzielący się pomysłami, informacjami i zasobami [Naisbitt, 1997: 235].

2 O ile nie zaznaczono inaczej, wszystkie przekłady z prac nietłumaczonych na polski A.M.D. i J.S. 
Sieci istnieją po to, by wymieniać informacje, polepszać wydajność i działalność zawodową oraz dzielić się innymi zasobami.

Pojęcie to można wiązać z pewną społeczną umiejętnością, obejmującą nawiązywanie kontaktów, budowanie relacji lub aktywowanie i utrzymywanie powiązań. Nelly Daszkiewicz wskazuje na tzw. zdolność sieciową, która oznacza umiejętność budowania sieci, czyli relacji i kontaktów pomiędzy ludźmi a organizacjami [Daszkiewicz, 2004: 83].

Pojęcie sieci odnoszone do organizacji należy rozumieć jako system połączeń pomiędzy ludźmi lub jednostkami organizacyjnymi, tworzony w celu wymiany informacji, pomysłów (idei) oraz zasobów [Lachiewicz, 2008: 7; Zakrzewska-Bielawska, 2011: 226]. Sieć powstaje wówczas, gdy przynajmniej dwie organizacje działają, pozostając ze sobą w trwałych relacjach [Thorelli, 1986: 37].

Podstawą funkcjonowania sieci jest kooperacja oparta na podziale celów i kompetencji, wspólnej pracy, zbiorowej odpowiedzialności i zaufaniu. Struktury sieciowe stanowią podstawę istnienia i funkcjonowania sieciowych form organizacyjnych, w których dynamika organizacyjna posiada znaczenie nadrzędne względem układu strukturalnego i funkcjonalnego. ,[...] sieć nie jest formą organizacyjną, która sama w sobie generuje przewagę i podnosi efektywność funkcjonowania [organizacji]. Jest środkiem, który odpowiednio zastosowany, pozwala działać skuteczniej w burzliwym otoczeniu" [Czakon, 2012: 17].

Praktyka funkcjonowania przedsiębiorstw w strukturach sieciowych pozwoliła na wyłonienie czterech głównych typów sieci [Brilman, 2002: 427]: zintegrowanych, sfederowanych, kontraktowych i stosunków bezpośrednich.

Rozwój technologii informacyjno-komunikacyjnych w istocie komplikuje obraz sieciowości, wprowadzając powszechność i duże zróżnicowanie występowania sieciowych form organizacyjnych. Dlatego organizację sieciową można postrzegać jako nowoczesną formę organizacyjną, jako innowacyjną metodę zarządzania bądź formę nawiązywania współpracy pomiędzy odrębnymi podmiotami gospodarczymi. Ravi S. Achrol definiuje organizację sieciową jako gęstą, wielowymiarową oraz wzajemną sieć relacji wymiany, w której podzielany system wartości określa role członków i ich odpowiedzialność [Achrol, 1997: 56-71]. Jakość relacji nawiązywanych pomiędzy uczestnikami sieci oraz sposób organizacji współdziałania w sieci mają decydujący wpływ na wyłonienie się organizacji sieciowej [Jarillo, 1988: 31-41]. Istotnym wyróżnikiem struktur sieciowych jest dominacja więzi poziomych [Jędralska, Kosiń, 2007: 13]. Więzi organizacji sieciowych charakteryzują się brakiem hierarchii, długim okresem zaangażowania, wielością ról i odpowiedzialności, wzajemnością oraz poczuciem przynależności [Czakon, 2012: 45]. Opisując elementy składowe konfigurujące sieć, Matthew G. Easton i Luis Araujo wskazują na uczestników sieci, których określają mianem węzłów, aktorów lub wierzchołków sieci, oraz na relacje zachodzące między uczestnikami [Easton, Araujo, 1994: 72-84]. Sieci międzyorganizacyjne częściej są definiowane przez charakterystykę procesów wymiany zachodzących pomiędzy węzłami niż przez charakterystykę samych węzłów. Świadczy to o tym, że za najważniejszy element sieci uznawane są relacje. Organizacje nawiązujące relacje pomiędzy sobą tworzą sieć i są uważane za węzły sieci [Bianchi, Bellini, 1991: 486-497]. 
Organizacje oraz pozostali uczestnicy sieci, włączając się w proces wartościotwórczy realizowany w sieci, konkurują o wygenerowaną w sieci wartość oraz partycypują w jej przechwytywaniu [Prahalad, Ramaswamy, 2000: 79-87]. Efektywność węzła w sieci, jego zdolność do przechwycenia (apriopriacji) największej ilości wygenerowanej w sieci wartości zależy od jego siły przetargowej i wynika z pozycji zajmowanej w sieci, zdeterminowanej rodzajem i charakterem relacji $z$ interesariuszami, oraz tożsamości strategicznej. Potencjał organizacji - węzła sieci, w zakresie kształtowania relacji z innymi węzłami w sieci w sposób efektywny i oparty na efektywności wykorzystywania zasobów - wpływa na pozycję organizacji (mikropozycję) w sieci względem innych uczestników sieci (węzłów), którzy nie potrafią nawiązać takich relacji lub robią to nieefektywnie. Znaczenie węzła w całej sieci jest określane mianem makropozycji, która odzwierciedla zdolność węzła w zakresie kształtowania relacji między zasobami i działaniami węzłów tworzących sieć [Johanson, Mattsson, 1988: 185-195].

Pozycjonowanie węzła w sieci jest ważne z punktu widzenia charakterystyk procesu wymiany wartości, który dokonuje się w sieci międzyorganizacyjnej. Każdy węzeł w sieci, pozostając $\mathrm{w}$ relacjach $\mathrm{z}$ innymi węzłami (uczestnikami sieci), jest zainteresowany wartością, którą może uzyskać wskutek tej wymiany. W sieci międzyorganizacyjnej są zatem realizowane procesy wartościotwórcze. Inicjatorami tych procesów są węzły dominujące, a wygenerowana wartość i możliwość jej przechwycenia w sieci zależą od dostępności zasobów oraz działań, jakie może podjąć węzeł wskutek relacji nawiązanych w sieci. Stąd pozycja zajmowana przez węzeł w sieci ma znaczenie kluczowe, gdyż wpływa na wartość możliwą do przejęcia przez pojedynczy węzeł.

W opisach struktury sieciowej punktem odniesienia jest struktura hierarchiczna. Podkreśla się, że w organizacji sieciowej w zasadzie całość komunikacji pionowej i stosunków kontroli zastępuje się stosunkami poziomymi. Formalne związki łączące jednostki organizacyjne zastępowane są powiązaniami partnerów, którymi są inne organizacje. Zasoby są zaś eksploatowane w taki sposób, aby wytwórcą skończonej całości nie była żadna z pojedynczych organizacji sieci, lecz sieć jako całość [Hatch, 2002: 195].

Strukturę sieciową konstytuują cztery cechy: współzależność zasobów między uczestnikami sieci; zaangażowanie w przedsięwzięcie przynajmniej kilku uczestników, z których każdy ma własne, czasami konkurencyjne interesy wobec pozostałych uczestników sieci; dominacja horyzontalnych kierunków wymiany; nieograniczony obszar funkcjonowania [Seok-Eun, 2003: 803].

Sieci konstruowane są z trzech głównych składowych: węzłów (ang. nodes), powiązań (ang. ties) oraz przepływów (ang. flows) [Seok-Eun, 2003: 803]. Węzeł to punkt połączony przynajmniej z jednym innym punktem, chociaż często funkcjonuje jednocześnie jako punkt łączący dwa inne lub więcej punktów [Barney, 2008: 37]. Powiązanie łączy jeden węzeł z innymi. Przepływy są tym, co przepływa między węzłami wzdłuż powiązań.

Przedstawiony wyżej syntetyczny przegląd pojęć dotyczący sieci organizacyjnej i jej składowych potwierdza powszechnie przyjęty pogląd, że współczesne organizacje odchodzą od organizacji zbudowanej wertykalnie, pionowo. Gospodarcze 
i technologiczne zmiany wywołały potrzebę poszukiwania nowych form organizacji. Rezultatem tych poszukiwań jest organizacja horyzontalna - sieć organizująca się wokół procesów, decentralizacji i współdziałaniu zarządzania zasobami. Zdaniem autorów pracy w takich organizacjach sieciowych kluczowe znaczenie mają relacje budowane na podstawie zasobów władzy i wiedzy. Relacje te sprzyjają, bądź nie, wymianie i konfiguracji między węzłami sieci.

\section{Władza w organizacji sieciowej}

W literaturze przedmiotu prezentowany jest pogląd, że sieć jest alternatywną do hierarchii i rynku formą koordynacji działalności gospodarczej [Powell, 1990: 298]. Podstawą tego poglądu jest przyjęcie jako kryteriów różnicujących m.in.: podstawy normatywnej, sposobów komunikacji (społecznej), metod rozwiązywania konfliktów, stopnia elastyczności, stopnia zaangażowania stron, atmosfery (klimatu) relacji, preferencji lub wyboru relacji łączących strony [Powell, 1990: 300; Murawiak, 2009: 18].

Zdaniem autorów niniejszego opracowania współczesne sieci organizacyjne są konstruowane przez cztery podstawowe metaidee: władzę, wiedzę, współdziałanie i współzawodnictwo. Stanowią one jednocześnie składniki tworzenia i rozwoju różnych sieci organizacyjnych, do których zalicza się sieci oparte na współpracy, dominacji, partnerstwie i konkurencji [Dereń, Malara, Skonieczny, 2017: 24-26].

Pojęcie władzy można zdefiniować różnie. W sposób obrazowy i ludyczny określa to Waldemar Stelmach, pisząc, że z władzą jest jak z ekwipunkiem u alpinistów albo gorsetem gipsowym u chorych na kręgosłup: jest ciężarem i przeszkadza, ale obejść się bez niego nie sposób. Nie ma żadnej organizacji bez władzy. Są natomiast różne jej rodzaje [Stelmach, 2010: 35].

W literaturze przedmiotu pojęcie władzy definiuje się jako zdolność grupy bądź jednostki do oddziaływania na dowolny aspekt funkcjonowania organizacji [Ansoff, 1985: 131]. Podkreśla się również, że władza to rodzaj relacji pomiędzy dwoma (lub więcej) osobami, w których zachowanie jednej zależy od zachowania drugiej. Jak pisze Robert Dahl: „A ma władzę nad B w takim zakresie, w jakim może spowodować, że B zrobi coś, czego w przeciwnym wypadku by nie zrobił" (ang. „A has power over B to the extent that he can get B to do something B would not otherwise do") [Dahl, 1957: 201]. Przy toczona definicja wskazuje na istotną cechę władzy: ma ona charakter relacyjny. Oznacza to, że osoba czy grupa ma władzę tylko w relacji z inną osobą czy grupą. A i B nie muszą być oczywiście osobami: w organizacji stosunki władzy obejmują nie tylko władzę interpersonalną, ale też stosunki między jednostkami organizacyjnymi czy szczeblami organizacyjnymi.

Zdolność relacyjną jako cechę władzy podkreśla również M. Castells, który twierdzi, że zdolność ta umożliwia ,[...] aktorowi społecznemu wywieranie asymetrycznego wpływu na decyzje innych aktorów społecznych w sposób sprzyjający umacnianiu jego woli, interesów i wyznawanych wartości” [Castells, 2013: 23]. Pojęcie aktora należy odnosić do różnych podmiotów podlegających 
działaniu władzy, funkcjonujących zarówno w otoczeniu konkurencyjnym (konkurenci, dostawcy, konsumenci), makrootoczeniu (aktorzy polityczni, ekonomiczni, społeczni, technologiczni, ekologiczni i prawni), jak i otoczeniu radykalnym (społeczności internetowe, prekariusze, uchodźcy, imigranci i terroryści) [Dereń, Skonieczny, 2017: 20-30].

Słusznie więc twierdzi Michel Foucault: ,władza jest wszędzie: nie dlatego, że wszystko obejmuje, ale dlatego że zewsząd się wyłania. Nie jest ani instytucją, ani strukturą, ani czyjąkolwiek potęgą. Jest nazwą użyczoną złożonej sytuacji strategicznej w danym społeczeństwie" [Foucault, 1998: 174-192]. Władza jest nie tylko represyjna, lecz także twórcza - produktywna, prowadzi do wiedzy, do budowania relacji i dokonywania przekształceń. W kontekście organizacyjnym zjawisko władzy, zwłaszcza zaś jej posiadanie i sprawowanie, ujmowane jest z wielu punktów widzenia. Wielość perspektyw postrzegania władzy i złożoności jej natury nie podważa faktu, że władza umożliwia koordynację w ramach struktur organizacyjnych wysiłków różnych ludzi, ukierunkowanych na osiągnięcie wspólnego celu, a w przypadku gdy sprawuje ją obdarzony charyzmą lider, władza staje się źródłem inspiracji i dodatkowej motywacji dla członków organizacji.

Literatura z zakresu teorii organizacji i zarządzania prezentuje różne wyjaśnienia pojęcia „władza”, traktuje ją jako „możliwość wywierania wpływu na innych ludzi, możliwość doprowadzania do zmiany postaw lub zachowań grup albo indywidualnych osób” [Stoner i in., 1997: 335]; „podstawowe źródło sprawowania kontroli nad członkami organizacji” [Stoner i in., 1997: 338]; ,zdolność do wpływania na zachowania innych” [Griffin, 1998: 494]; ,[władza - A.M.D. i J.S.] oznacza prawo do kontroli i egzekwowania posłuszeństwa pracowników [...] oraz obowiązek posłuszeństwa wobec osób dysponujących uprawnioną władzą" [Katz, Kahn, 1979, cyt. za: Strelau, 2003: 323]; „to możność kierowania ludźmi [...], pod warunkiem przyzwolenia podwładnych, i ich posłuszeństwa" [Zieleniewski, 1964: 394]; ,„władza - A.M.D i J.S.] stanowi cechę pewnej relacji między ludźmi, a nie atrybut danego człowieka” [Czerska i in., 2001: 101]; „to stosunek międzyosobowy, w którym jeden osobnik, podwładny, akceptuje decyzje powzięte przez innego osobnika, przełożonego, przyzwalając na to, aby ta decyzja wpłynęła bezpośrednio na jego (podwładnego) zachowanie się" [Bednarski, 2001: 201]; „[władza - A.M.D i J.S.] polega na tym, że dany aktor może narzucić swoją wolę innym aktorom społecznej interakcji” [Weber, 2002, cyt. za: Strelau, 2003: 380]; „,jest szansą lub faktycznym podejmowaniem decyzji o zachowaniu się grup społecznych w organizacjach" [Doktór, 1982: 199].

Przy toczone definicje pozwalają na ukazanie różnych aspektów zjawiska władzy. Przede wszystkim, taki, że władzę zawsze należy łączyć z interakcjami zachodzącymi pomiędzy ludźmi; z władzą zawsze łączy się zależność (im większa zależność tym większa władza); władza dotyczy co najmniej dwóch stron - strony wywierającej wpływ (przełożonego, sprawującego władzę) i strony ulegającej, posłusznej wpływowi (podwładnego) - władza może wynikać z różnych źródeł.

W opisywanej tutaj logice sieciowej istota władzy się nie zmienia. Władza jest nadal zdolnością relacyjną narzucania woli i wartości przez jednych aktorów społecznych innym, którzy są uczestnikami sieci. Zakres tej zdolności relacyjnej 
w sieci jest znacznie szerszy niż w organizacjach opartych na hierarchii dzięki technologiom komunikacyjno-informatycznym. Nadal też jednostki lub grupy, które nie posiadają władzy, chcą ją zdobyć, a ci, którzy ją posiadają - chcą ją utrzymać, niekiedy za wszelką cenę. Zmienia się natomiast charakter i źródło władzy. Władzę w sieci charakteryzuje: mniejsza hierarchiczna zależność pomiędzy uczestnikami sieci, dynamika podejmowanych decyzji i ich rozproszony charakter pomiędzy węzłami sieci. Władza w sieci oparta jest na zasadzie pomocniczości i deliberacji jako formach wymiany informacji i działania. Decyzje władzy sieciowej zapadają na podstawie porozumienia pomiędzy uczestnikami oraz dialogu i współpracy z otoczeniem.

Jeśli chodzi o źródło władzy w sieci, to jest nim wiedza. Zasoby wiedzy są również przedmiotem wymiany w sieci i podstawą budowania relacji między jej uczestnikami. Na głęboki i wielokierunkowy związek pomiędzy rozwojem wiedzy a relacjami władzy wskazywał M. Foucault. Jego analizy władzy i wiedzy wykraczają daleko poza grę interesów i ideologii, poza badanie społecznych uwarunkowań rozwoju wiedzy i nauki. Każdy system wiedzy wyrasta ze społecznie ukształtowanej komunikacji. Ten ścisły związek społeczeństwa i wiedzy zakłada powszechność relacji władzy.

W koncepcji M. Foucaulta mechanizmy przymusu i mechanizmy poznania są ze sobą powiązane w sposób fundamentalny, a relację między władzą a wiedzą charakteryzuje zwrotność. M. Foucault pisze o tym następująco:

[...] trzeba będzie także być może zarzucić tradycyjne wyobrażenia, że wiedza rodzi się tam tylko, gdzie ustają związki z władzą i można ją rozwijać jedynie poza jej nakazami, wymogami i interesami. [...] wypada raczej uznać, że władza produkuje wiedzę (ale nie dlatego po prostu, że faworyzuje ją, gdy ta jej służy, lub wykorzystuje, gdy jest użyteczna); że władza i wiedza wprost ze sobą się wiążą; że nie ma relacji władzy bez skorelowanego z nimi pola wiedzy, ani też wiedzy, która nie zakłada i nie tworzy relacji władzy. [...]. Krótko mówiąc - to nie działanie podmiotu poznającego tworzy wiedzę użyteczną dla władzy lub wobec niej oporną, ale władza wiedza, procesy i walki, którym podlega i z których się składa, wyznaczają możliwe formy i dziedziny poznania [cyt. za: Kochanowski, 2007: 76].

Wiedza nie powstaje poza wpływem politycznym, systemowym, służąc uzasadnieniu przekazów, treści, norm, którymi posługuje się władza, a władza kształtuje wiedzę tak, by dzięki niej mogła efektywniej kontrolować jednostki, które nie są tej kontroli świadome. Połączenie wiedza-władza jest u M. Foucaulta swego rodzaju instrumentem, służącym stabilizacji systemu dominacji i jego systemu znaczeń. Wytwarza własną prawdę, moralność i znaczenia.

Przedstawione wyżej rozważania wskazują, że wiedza nie tylko wpływa na zachowanie pojedynczych osób, lecz także na zachowanie organizacji działających według logiki sieciowej, w których wiedza jest kluczowym narzędziem pozyskania i utrzymania władzy. Wytwarzana wiedza dostarcza organizacji informacji pozwalających na interpretację rzeczywistości, w której ona funkcjonuje. Wiedza generuje działania władzy, które stają się określonymi praktykami społecznymi. 
Z kolei te praktyki formują zasoby wiedzy w organizacji i sposób korzystania z nich. To ważna konstatacja, bowiem wynika z niej, iż to wiedza legitymizuje władzę.

\section{Swobodna wymiana i dzielenie się zasobami władzy i wiedzy w sieci}

W literaturze poświęconej problematyce funkcjonowania organizacji sieciowych zwraca się uwagę na istotę relacji występujących pomiędzy uczestnikami sieci. Milena Ratajczak-Mrozek dokonuje przeglądu cech relacji sieciowych proponowanych w literaturze przedmiotu. Twierdzi ona, że relacje sieciowe charakteryzują: ciągła interakcja (powiązania formalne i nieformalne, długoterminowość), współzależność (powiązania w zakresie zasobów, podmiotów i działań) i nieskończoność (brak wyraźnych granic i struktury) [Ratajczak-Mrozek, 2009: 75-82].

Najczęściej autorzy wskazują na bliskość, komplementarność i długoterminowość relacji między uczestnikami sieci [Hakansson, 1982: 10-26]. Inni autorzy podkreślają takie cechy relacji jak: specyfika powiązania (dynamika, stopień wykorzystania potencjału, charakter wymiany oraz interakcji), wzajemność (stopień wzajemności, symetryczność, posiadanie władzy, zależność od zasobów), osobliwość (wyróżniające cechy), długoterminowe podejście, związki z otoczeniem [Ford i in., 1993: 26-41].

Według Wojciecha Czakona istotę relacji sieciowych charakteryzują wymiana (informacyjna, materialna i energetyczna), zaangażowanie (pogłębianie i poszerzanie istniejących relacji wymiany) i wzajemność (obejmująca wymianę informacji oraz skoordynowane podejmowanie decyzji na tej podstawie) [Czakon, 2005: 10].

Z kolei Krzysztof Łobos i Karolina Mazur na podstawie pogłębionej analizy wybranych pozycji literaturowych dotyczących badania zaufania między organizacjami zdefiniowali kilkanaście miar efektywności tych związków, które zakwalifikowali do trzech grup [Łobos, Mazur, 2016: 813-814]:

1) mierników efektywności procesowej: np. efektywność sprzedaży, intensywność konkurencyjna, koordynacja partnerów, trwałość aliansu, efektywność produktu, skuteczność, wydajność, komunikacja, integracja strategiczna;

2) mierników efektywności finansowej, np. wzrost sprzedaży, efektywność finansowa partnera, wzrost zysku, efektywność eksportu, efektywność sprzedaży, efektywność dostawców;

3) mierników efektywności społecznej, np. dzielenie się wiedzą, satysfakcja z relacji, zaangażowanie, responsywność aliansu.

Przedstawione wyżej opinie ukazują zbieżność w ocenie podstawowych cech charakteryzujących relacje pomiędzy uczestnikami sieci. Zdaniem autorów pracy kluczową cechą, a zarazem podstawą funkcjonowania samej sieci organizacyjnej jest swobodna wymiana i dzielenie się wiedzą między jej uczestnikami. Decydujące przy tym znaczenie mają charakter wiedzy będącej przedmiotem wymiany, 
jej kondycja rynkowa, czy też użyteczność definiowana jako umiejętność wykorzystania jej w praktyce. Charakter i rodzaj wiedzy decydują o dominującej lub koordynującej władzy w sieci. Niniejszy pogląd wpisuje się w przyjęte w literaturze rozważania na temat władzy i współpracy jako czynników kształtujących relacje w strukturach sieciowych.

Podejście oparte na władzy wskazuje na trzy wymiary relacji: stopień obopólności (ang. mutuality), symetryczność oraz strukturę władzy. Wzajemność jest tu cechą stopniowalną, pojawiającą się jako skutek dwustronnych dążeń do dominacji partnera. Takie rozumienie pojawia się u tych autorów, którzy w nawiązywaniu więzi relacyjnych dostrzegają próbę ograniczenia zasobowych słabości organizacji. Usiłuje ona wtedy przejąć kontrolę nad zasobami partnerów [Holmlund, 1997: 304-311].

Podejście oparte na współpracy odnosi się do równowagi, dwustronności i równości stron [Olivier, 1990: 241-265]. W tym ujęciu nawiązywanie relacji sieciowych stanowi wyraz wspólnych celów lub możliwości pełniejszego osiągania celów we współdziałaniu z innymi organizacjami. Zakłada się, że niedoskonałość zasobowa organizacji oraz proces tworzenia relacji są dobrowolne i obopólne, a to oznacza, że nie odbywają się one pod przymusem, w warunkach dominacji. Strony antycypują przyszłe korzyści ze współpracy, a to skłania je do harmonijnego odwzajemniania wysiłków.

\section{Podsumowanie}

Przedstawione rozważania wskazują, że władza jest nadal kluczowym czynnikiem budującym relacje między organizacjami będącymi uczestnikami sieci. Tę władzę wzmacnia i jest jej źródłem wiedza, rozumiana jako podstawowy czynnik produkcji oraz zasób niematerialny współczesnej organizacji. W strukturze sieciowej jest ona zasobem relacyjnym łączącym różnych uczestników sieci. To wiedza decyduje o zakresie i charakterze swobodnej wymiany, jak i dobrowolnego dzielenia się z innymi w sieci. Kształtuje ona również charakter władzy w sieci, która przyjmuje postać dominacji, współpracy, partnerstwa lub konkurencji [Dereń, Malara, Skonieczny, 2017: 25]. Zarysowany tu problem wymaga dalszych badań i analiz, które zweryfikują jego użyteczność dla praktyki gospodarczej.

\section{Bibliografia}

Achrol R.S. (1997), Changes in the Theory of Interorganizational Relations in Marketing: Toward a Network Paradigm, „Academy of Marketing Science Journal”, 25(1).

Ansoff H.I. (1985), Zarządzanie strategiczne, tłum. K. Obłój, J.N. Sajkiewicz, Państwowe Wydawnictwo Ekonomiczne, Warszawa. 
Barney D. (2008), Społeczeństwo sieci, tłum. M. Fronia, Sic!, Warszawa.

Bednarski A. (2001), Zarys teorii organizacji i zarzadzania, Towarzystwo Naukowe Organizacji i Kierownictwa „Dom Organizatora”, Toruń.

Bianchi P., Bellini N. (1991), Public Policies for Local Networks of Innovators, „Research Policy", 20(5).

Brilman J. (2002), Nowoczesne koncepcje i metody zarządzania, tłum. K. Bolesta-Kukułka, Polskie Wydawnictwo Ekonomiczne, Warszawa.

Castells M. (2007), Społeczeństwo sieci, tłum. J. Stawiński i in., Wydawnictwo Naukowe PWN, Warszawa.

Castells M. (2013), Władza komunikacji, tłum. J. Jedliński, P. Tomanek, Wydawnictwo Naukowe PWN, Warszawa.

Czakon W. (2005), Istota relacji sieciowych przedsiębiorstwa, „Przegląd Organizacji”, 9.

Czakon W. (2012), Sieci w zarzadzaniu strategicznym, Oficyna a Wolters Kluwer business, Warszawa.

Czerska M., Rutka R., Czermiński A., Nogalski B., Apanowicz J. (2001), Zarządzanie organizacjami, Towarzystwo Naukowe Organizacji i Kierownictwa „Dom Organizatora”, Toruń.

Dahl R. (1957), The Concept of Power, „Behavioral Science”, 2.

Daszkiewicz N. (2004), Strategie internacjonalizacji matych i średnich przedsiębiorstw we współczesnej gospodarce, Scientific Publishing Group, Gdańsk.

Dereń A.M., Malara Z., Skonieczny J. (2017), Władza, wiedza, współdziałanie i współzawodnictwo jako idee tworzenia sieci organizacyjnych, „Przegląd Organizacji”, 8.

Dereń A.M., Skonieczny J. (2017), Social Responsibility of Organization Towards New and Radical Market Actors, „Prace Naukowe Uniwersytetu Ekonomicznego we Wrocławiu. Research Papers of Wroclaw University of Economics", 464: Social Responsibility of Organizations. Old - New Stakeholders?

Doktór K. (1982), Władza, kierowanie i przywództwo w organizacjach, „Studia Socjologiczne", 1-2.

Easton M.G., Araujo L. (1994), Market Exchange, Social Structures and Time, „European Journal of Marketing", 28(3).

Ford D., Hakansson H., Johanson J. (1993), How do Companies Interact? Understanding Business Markets: Interaction, Relationships and Networks, D. Ford (ed.), Academic Press Harcourt Brace \& Company Publishers, London.

Foucault M. (1998), Podmiot i władza, tłum. J. Zychowicz, „Lewą Nogą”, 10.

Griffin R.W. (1998), Podstawy zarządzania organizacjami, tłum. A. Jankowiak, Wydawnictwo Naukowe PWN, Warszawa.

Hakansson H. (red.) (1982), International Marketing and Purchasing of Industrial Goods: An Interaction Approach, John Wiley \& Sons, Chichester.

Hatch M.J. (2002), Teoria organizacji, tłum. P. Łuków, Wydawnictwo Naukowe PWN, Warszawa.

Holmlund M. (1997), What Are Relationships in Business Networks, „Management Decision", 35(4).

Jarillo C. (1988), On Strategic Networks, „Strategic Management Journal”, 9(1).

Jędralska K., Kosiń P. (2007), Zarządzanie przez controlling w sieci wartości, Wydawnictwo Akademii Ekonomicznej im. Karola Adamieckiego, Katowice. 
Johanson J., Mattsson L.G. (1988), Internationalisation in Industrial Systems - a Network Approach [w:] N. Hood, J.E. Vahlne (eds.), Strategies in Global Competition, Croom Helm, New York.

Katz D., Kahn R. (1979), Społeczna psychologia organizacji, tłum. B. Czarniawska, Warszawa.

Kelly K. (1994), Out of Control: The Rise of Neo-biological Civilization, Addison-Wesley, Reading (Mass.).

Kochanowski J. (2007), Wiedza jako władza i wiedza jako opór. Wokół koncepcji Marka Olssena, Johna Codda i Anne-Marie O’Neill, „Nauka i Szkolnictwo Wyższe”, 1(29).

Lachiewicz S. (2008), Organizacje sieciowe we wspótczesnej gospodarce [w:] S. Lachiewicz (red.), Komunikacja wewnętrzna w organizacjach sieciowych, Wydawnictwo Politechniki Łódzkiej, Łódź.

Łobos K., Mazur K. (2016), Wskaźniki efektywności w badaniach nad zaufaniem międzyorganizacyjnym, „Finanse, Rynki, Finansowe, Ubezpieczenia”, 1(79).

Naisbitt J. (1997), Megatrendy - dziesięć nowych kierunków zmieniających nasze życie, tłum. P. Kwiatkowski, Wydawnictwo Zysk i S-ka, Poznań.

Murawiak K. (2009), Znaczenie teorii sieci w wyjaśnianiu działalności gospodarczej przedsiębiorstw [w:] M. Winiarski (red.), Nowe idee początku XXI w., Uniwersytet Wrocławski, Wydziała Prawa, Administracji i Ekonomii, Wrocław.

Olivier Ch. (1990), Determinants of Interorganizational Relationship: Integration and Future Directions, „Academy of Management”, 15(2).

Powell W.W. (1990), Neither Market Nor Hierarchy: Network Forms of Organization, „Research in Organizational Behavior", 12.

Prahalad C.K., Ramaswamy V. (2000), Co-opting Customer Competence, „Harvard Business Review", 78(1).

Ratajczak-Mrozek M. (2009), Główne cechy relacji sieciowych przedsiębiorstw (podejście sieciowe, network approach), „Organizacja i Kierowanie”, 4(138).

Rifkin J. (2016), Spoleczeństwo zerowych kosztów krańcowych. Internet przedmiotów, ekonomia współdzielenia, zmierzch kapitalizmu, tłum. A.D. Kamińska, Wydawnictwo Studio Emka, Warszawa.

Seok-Eun K. (2003), Networks, Organizational [w:] J. Rabin, (ed.), Encyclopedia of Public Administration and Public Policy, vol. 1, Marcel Dekker, Inc., New York.

Stelmach W. (2010), Władza i kierowanie. Teorie i praktyki biurokracji, Wydawnictwo Placet, Warszawa.

Stoner J.A.F., Freeman R.E., Gilbert D.R. Jr. (1997), Kierowanie, tłum. A. Ehrlich, Polskie Wydawnictwo Ekonomiczne, Warszawa.

Strelau J. (red.) (2003), Psychologia. Podręcznik akademicki, t. 1: Podstawy psychologii, Gdańskie Wydawnictwo Psychologiczne, Gdańsk.

Weber M. (2002), Gospodarka i społeczeństwo. Zarys socjologii rozumiejącej, tłum. i wstęp D. Lachowska, Wydawnictwo Naukowe PWN, Warszawa.

Thorelli H.B. (1986), Networks Between Markets and Hierarchies, „Strategic Management Journal", 7. 
Zieleniewski J. (1964), Organizacja zespołów ludzkich, Wydawnictwo Naukowe PWN, Warszawa.

Zakrzewska-Bielawska A. (2011), Relacje między strategia a struktura organizacyjna $w$ przedsiębiorstwach sektora wysokich technologii (Zeszyty Naukowe Politechniki Łódzkiej, 1095), Wydawnictwo Politechniki Łódzkiej, Łódź. 